For my friends George and Elizabeth Wood 


\section{Other books by Brian McFarlane include}

Four from the Forties: Arliss, Crabtree, Knowles and Huntington, Manchester University Press, 2018

Making a Meal of It: Writing about film, Monash University Publishing, 2018

Class-Act: The Lives and Careers of Googie Withers and John McCallum, Monash University Publishing, 2015

Twenty British Films: A Guided Tour, Manchester University Press, 2015

The Encyclopedia of British Film: Fourth Edition (ed.), Manchester University Press, 2014

Real and Reel: The Education of a Film Obsessive and Critic, Manchester University Press, 2011

Michael Winterbottom (British Film Makers) (with Deane Williams), Manchester University Press, 2009

The British 'B' Film (with Steve Chibnall), British Film Institute, 2009

Screen Adaptations: Charles Dickens' Great Expectations, Methuen Drama, 2008

The Cinema of Britain and Ireland (ed.), Columbia University Press, 2005

Lance Comfort (British Film Makers), Manchester University Press, 2000

The Oxford Companion to Australian Film (with Geoff Mayer and Ina Bertrand), Oxford University Press Australia and New Zealand, 1999

An Autobiography of British Cinema, Methuen Publishing Ltd, 1997

Novel to Film: An Introduction to the Theory of Adaptation, Oxford University Press, 1996

Sixty Voices: Celebrities Recall the Golden Age of British Cinema, British Film Institute, 1993

New Australian Cinema: Sources and Parallels in American and British Film (with Geoff Mayer), Cambridge University Press, 1992

Viewpoints on the Nineteenth-Century Novel (ed.), Longman Cheshire, 1992

Viewpoints on Film (ed.), Longman Cheshire, 1992

Australian Cinema, Columbia University Press, 1988

Cross-Country: A Book of Australian Verse (with John Barnes), Heinemann Educational Australia, 1988

Words and Images: Australian Novels into Film, Heinemann, 1983

Martin Boyd's 'Langton Novels', Edward Arnold, 1980 